\title{
Therapeutic effects of hydralazine on renal ischemia-reperfusion injury in rat
}

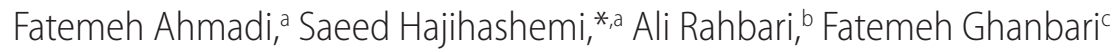

\author{
${ }^{a}$ Department of Physiology, Faculty of Medicine, Arak University of Medical Sciences, Arak, Iran. \\ ${ }^{b}$ Department of Pathology, Arak University of Medical Sciences, Arak, Iran. \\ 'Department of Pharmacology, Islamic Azad University, Arak Branch, Arak, Iran. \\ Corresponding author: Saeed Hajihashemi (Email: Hajihashemi@arakmu.ac.ir) \\ (Submitted: 14 July 2019 - Revised version received: 23 August 2019 - Accepted: 05 September 2019 - Published online: 26 December 2019)
}

\begin{abstract}
Objective Renal ischemia-reperfusion (I-R) induces acute kidney injury (AKI). In this study, the effect of hydralazine was investigated on the renal injury induced by the I-R in rats.

Methods AKI was induced with bilateral obstruction of the renal artery and vein for $20 \mathrm{~min}$ following $24 \mathrm{~h}$ of reperfusion. Hydralazine ( $5 \mathrm{mg} /$ $\mathrm{kg}$ ) was injected intraperitoneally as post-treatment.

Results Hydralazine significantly increased the levels of renal clearance of creatinine and renal blood flow, while they were decreased by I-R. Also, hydralazine significantly improved levels of serum electrolytes (sodium and potassium) that were impaired by I-R. The tissue malondialdehyde levels were significantly suppressed by hydralazine.

Conclusion According to the results, the post-treatment of hydralazine had a therapeutic effect on renal I-R because of improved ion reabsorption and excretion and increased renal blood flow and glomerular filtration rate and decreased lipid peroxidation.

Key words hydralazine, renal ischemia-reperfusion injury, rat
\end{abstract}

\section{Introduction}

Acute kidney injury (AKI) is a complex clinical disorder simply meaning a sudden loss of kidney function induced by damage to the kidneys that causes structural and functional injury. ${ }^{1}$ AKI is diagnosed based on significant increase in serum $\mathrm{Cr}$, oliguria, and anuria. ${ }^{2}$ The causes of AKI are divided into three categories: pre-renal, post-renal, and intrinsic kidney disease. Among these three categories, only intrinsic disorder represents the actual AKI state, while the other two are the result of extra renal disorders, leading to a decrease in glomerular filtration rate (GFR). If the conditions of these two classes are durable, it will eventually lead to cellular damage and intrinsic kidney disease. ${ }^{1}$

The ischemia-reperfusion (I-R) model is one of the animal models used for the fundamental and therapeutic studies in $\mathrm{AKI}^{3}$. I-R activates apoptosis and necrosis. The necrosis is characterized by cellular swelling with a membrane surface rupture. Necrotic cells stimulate the immune system resulting in filtration of inflammatory cells along with the release of cytokines. ${ }^{4}$

Apoptosis activates caspase's complex cascade. In vascular dysfunction, increased vascular permeability, endothelial cell inflammation, activation of the complement system, loss of fluid in the interstitial tissue, vasoconstriction, leukocyte activation, and endothelial-leukocyte reaction result in further damage. ${ }^{5}$

Hydralazine is used as an antihypertensive agent which reduces the contraction responses of a number of contractile agents. Hydralazine is a direct arteriolar vasodilator that controls the pregnancy's high blood pressure with a half-life of 1 h. ${ }^{6}$ Hydralazine activates guanylate cyclase; vasodilation effect does not directly, but indirectly releases endogenous nitric oxide (NO) from endothelial cells, by controlling the prolyl-hydroxylase domain protein and activating the hypoxia-inducible factor (HIF) pathway. Hydralazine also helps to restore the balance between $\mathrm{NO}$ and superoxide in endothelial dysfunction by inhibiting NADPH oxidase. ${ }^{7}$ HIF-1 can increase NO production by multiple mechanisms, including increasing the expression of iNOS and COX4-2. ${ }^{8}$ Considering the characteristics of hydralazine in releasing endogenous $\mathrm{NO}^{9,10}$; in this study, we aim to investigate the effects of hydralazine post-treatment administration on renal injury caused by I-R.

\section{Materials and Methods}

This experimental study was performed on 24 Wistar rats weighing 250-300 g. Rats were housed at $12 \mathrm{~h}$ of darkness and $12 \mathrm{~h}$ of brightness at room temperature of $23 \pm 2^{\circ} \mathrm{C}$ with free access to the food and water. The experiments were performed on the rats in accordance with the guidelines and regulations and ethical codes approved by the Monitoring Committee for Laboratory Animals of Arak University of Medical Sciences.

The study groups included: (1) control group: did not receive the drug; (2) sham group: under anesthesia, only the kidneys were exposed without any ischemia; (3) I-R group: bilateral renal artery and vein occlusion for $20 \mathrm{~min}$; then with $24 \mathrm{~h}$ reperfusion; (4) hydralazine treatment group: bilateral renal artery and vein occlusion for $20 \mathrm{~min}$ and then hydralazine $(5 \mathrm{mg} / \mathrm{kg}$, NOVAPLUS, USA) +24 ho immediately after reperfusion initiation. ${ }^{9-11}$

To induce AKI, the animals were weighed first and then sodium thiopental ( $25 \mathrm{mg} / \mathrm{kg}$; Sandoz, $\mathrm{GmbH}$, Estonia) was injected intraperitoneally into the animal, ${ }^{12}$ and after shaving the back hair, $1.5 \mathrm{~cm}$ incisions were made on either side of the midline using scissors and forceps. The artery and vein of both kidneys were blocked using a special clamp for $30 \mathrm{~min}$, instantly after the end of the period, the obstruction was removed and the surgical area sutured with silk thread 3-0 and the animals were kept in a separate cage for recovery. ${ }^{11}$

After recovery, the rats were placed in metabolic cages and the urine was collected for $12 \mathrm{~h}$. Urine specific gravity was 
determined. After $24 \mathrm{~h}$ of reperfusion, the rats' systolic blood pressure was measured from the tail by using a Power Lab instrument (AD Instruments, Australia) and the mean of systolic blood pressure was calculated for a rat. ${ }^{13,14}$ The rats were anesthetized and a longitudinal cut was created in the abdomen with a blade. After separation of the artery and vein of the left kidney, after stabilization of amount of blood flow, the renal blood flow (RBF) was recorded for $30 \mathrm{~min}$ by using flow meter of Power Lab instrument (T402, America) ${ }^{15,16}$ and the mean of blood flow was measured for $30 \mathrm{~min}$. The blood sample was taken from the abdominal aorta by syringe of cold heparin. After plasma extraction, the concentration of creatinine $(\mathrm{Cr})$ and blood urea nitrogen (BUN) was measured in the serum and urine samples by using the Auto Analyzer. (Selectra-XL, Netherlands). ${ }^{17}$ The concentration of sodium and potassium were measured by a flame photometer (SEAC-20Fp, Italy). Osmolarity of urine and plasma samples was measured using a Osmometer (Gonotec Osmomat-030, Germany). ${ }^{18,19}$

Renal clearance of creatinine $\left(\mathrm{C}_{\mathrm{Cr}}\right)$, absolute and relative excretions of potassium and sodium was calculated using the following formula:

$$
\mathrm{C}_{\mathrm{Cr}}(\mu \mathrm{l} / \mathrm{min} / \mathrm{gkw})=\left(\mathrm{V}^{\circ} / 1000 \times \mathrm{U}_{\mathrm{Cr}}\right) / \mathrm{P}_{\mathrm{Cr}}
$$

Absolute excretion of sodium: $\mathrm{U}_{\mathrm{Na}} \mathrm{V}^{\circ}(\mu \mathrm{mol} / \mathrm{min} / \mathrm{gkw})=$ $\left(\mathrm{V}^{\circ} \times \mathrm{U}_{\mathrm{Na}}\right) / 1000$.

Absolute excretion of potassium: $\mathrm{U}_{\mathrm{K}} \mathrm{V}^{\circ}(\mu \mathrm{mol} / \mathrm{min} / \mathrm{gkw})=$ $\left(\mathrm{V}^{\circ} \times \mathrm{U}_{\mathrm{K}}\right) / 1000$. 100

Relative excretion of sodium: $\mathrm{FE}_{\mathrm{Na}}=\left(\mathrm{U}_{\mathrm{Na}} \times \mathrm{P}_{\mathrm{Cr}}\right) /\left(\mathrm{P}_{\mathrm{Na}} \times \mathrm{U}_{\mathrm{Cr}}\right) \times$ 100.

Relativeexcretion of potassium: $\mathrm{FE}_{\mathrm{K}}=\left(\mathrm{U}_{\mathrm{k}} \times \mathrm{P}_{\mathrm{Cr}}\right) /\left(\mathrm{P}_{\mathrm{k}} \times \mathrm{U}_{\mathrm{Cr}}\right) \times$

Both kidneys separately were removed and weighed, then they were cut into two halves. For the MDA (malondialdehyde) and FRAP (Ferric reducing ability of plasma) experiments, the right kidney was placed in the liquid nitrogen and immediately transferred to the $-20^{\circ} \mathrm{C}$ freezer. The Ohkawa method was used for MDA experiment, indicating the level of lipid peroxidation by MDA. In addition, the Benzie \& Strain method was used for the FRAP assay. ${ }^{20,21}$

For histological study, after removing the left kidney capsule, it was placed in $10 \%$ formalin buffer and after fixation, stages of dehydration, clarification, paraffin embedding was performed. After section cutting and preparation of 5-micron sections, slices were mounted and stained with hematoxylin and eosin. After preparation the slides, tissue analysis was performed by an expert pathologist. ${ }^{14,16}$

The changes in glomerular and tubular and vascular structure were analyzed. Glomerulus diameter and Bowman's space size, percentage of injuries in tubule and glomerulus, the number of red blood cells (RBCs) in glomeruli, the shedding of tubular cells, formation of cast proteins in the lumen, tubular cells necrosis and the formation of vacuoles within the cells were examined.

Based on the severity of injuries in the glomerular and renal parenchyma, the quantity of damage was graded as follows: "Grade 0"; 1-25\% damage, "Grade 1"; 25-50\% damage, "Grade 2"; 50-75\% damage, "Grade 3"; and 75-100\% damage, "Grade 4".22

Finally, the data were presented as the mean \pm standard error of the mean (S.E.M.). For statistical analysis, SPSS software version 25 (SPSS software, Chicago, IL, USA), one-way ANOVA, Tukey test, Kruskal-Wallis multiple comparison test and Dunnett test were employed at $P \leq 0.05$ as the significance level for statistical analysis. ${ }^{23}$

\section{Results}

\section{Post-Treatment Effects of Hydralazine on the RBF and Systolic Blood Pressure}

The results indicated RBF decreased significantly in the I-R groups $(6.42 \pm 0.3 \mathrm{ml} / \mathrm{min}, P<0.001)$ compared to the control and sham group $(8.5 \pm 0.2 \mathrm{ml} / \mathrm{min}, P<0.01)$. In the hydralazine-treated rats the RBF significantly increased $(9.04 \pm 0.4 \mathrm{ml} /$ min, $P<0.01)$ compared to the I-R group, while there was no significant difference between the control group and the sham group. The systolic blood pressure did not show a significant difference between the groups ( $\bullet$ Fig. 1).

\section{Post-Treatment Effects of Hydralazine on Renal Clearance of Creatinine $\left(C_{c}\right)$, Absolute Excretion of Sodium $\left(U_{\mathrm{Na}} V^{\circ}\right)$ and Potassium $\left(U_{k} V^{\circ}\right)$ and Relative Excretion of Sodium ( $\left.F E_{N a}\right)$ and Potassium ( FE $_{k}$ )}

Results showed that renal creatinine clearance was significantly decreased in the I-R groups $(0.008 \pm 0.005 \mu \mathrm{l} / \mathrm{min}$ gkw; $P<0.001)$ compared to the control and sham $(0.05 \pm 0.01 \mu \mathrm{l} /$ min $\mathrm{gkw})$. In the hydralazine-treated rats, the renal clearance
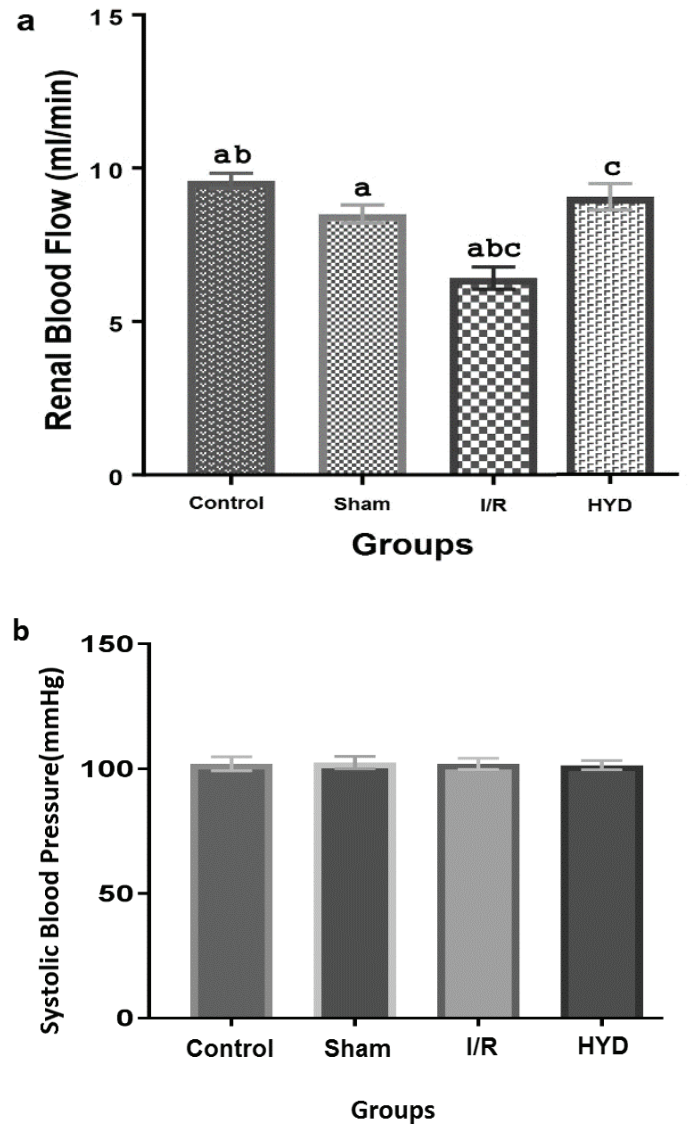

Fig. 1 Comparison of (a) renal blood flow and (b) systolic blood pressure among the groups. Similar characters represent significant differences between the groups. Results are expressed as mean \pm the standard Deviation (SD) for six rats in each group. 
Table 1. Comparison of creatinine clearance (CCr), absolute ( $\left(\mathbf{U N a V}^{\circ}\right)$ and relative ( $\left.\mathrm{FENa}\right)$ excretions of sodium and absolute $\left(\mathbf{U}_{\mathbf{k}} \mathbf{V}^{\circ}\right)$ and relative (FEk) excretions of potassium

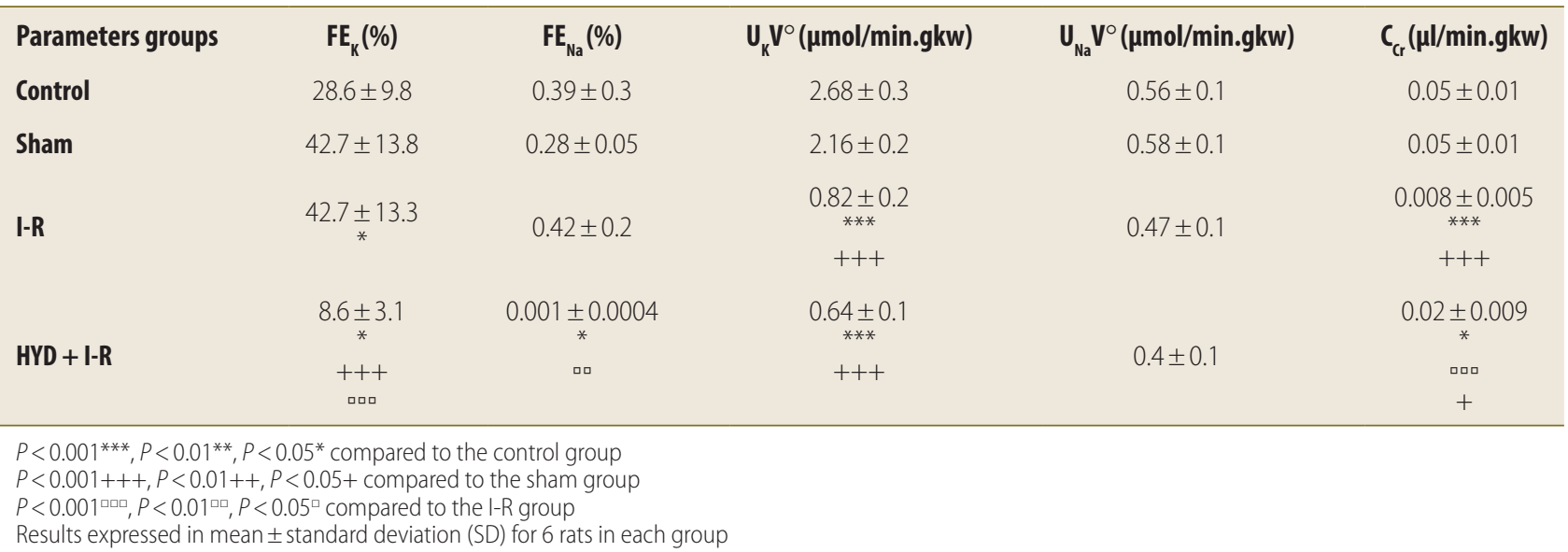

of creatinine $(0.02 \pm 0.009 \mu \mathrm{l} / \mathrm{min}$ gkw; $P<0.05)$ significantly increased in Compare to the I-R group $(0.008 \pm 0.005 \mu \mathrm{l} /$ min gkw; $P<0.001)$.

The relative excretion of sodium $\left(\mathrm{FE}_{\mathrm{Na}}\right)$ was not increased significantly in the I-R group compared to the control group $(0.42 \pm 0.2 \%$ vs. $0.39 \pm 0.3 \%)$.

The $\mathrm{FE}_{\mathrm{Na}}$ in the hydralazine group was significantly lower than that of the I-R group $(0.001 \pm 0.0004$ vs. $0.42 \pm 0.2 \%$; $P<0.01)$ and control group $(0.001 \pm 0.0004$ vs. $0.39 \pm 0.3 \%$; $P<0.05)$. The $\mathrm{FE}_{\mathrm{Na}}$ control group was not significantly different from the sham group ( $\vee$ Table $\mathbf{1}$ ).

In the I-R group the $\mathrm{FE}_{\mathrm{K}}$ showed a significant increase compared to the control group. ( $47.28 \pm 13.3 \%$ vs. $28.6 \pm 9.8 \%$; $P<0.05)$. The $\mathrm{FE}_{\mathrm{K}}$ significantly decreased in the hydralazine-treated rats compared to the control group $(8.6 \pm 3.1 \%$ vs. $28.6 \pm 9.8 \% ; P<0.05)$, sham group $(8.6 \pm 3.1 \%$ vs. $42.74 \pm 13.8 \%$; $P<0.001)$ and I-R group $(8.6 \pm 3.1 \%$ vs. $47.28 \pm 13.3 \%$; $P<0.001)(\vee$ Table 1 ).

The absolute excretion of sodium $\left(\mathrm{U}_{\mathrm{Na}} \mathrm{V}^{\circ}\right)$ did not show any significant difference among the groups. The $\mathrm{U}_{\mathrm{k}} \mathrm{V}^{\circ}$ in the I-R group $(0.82 \pm 0.2 \mu \mathrm{mol} / \mathrm{min}$ gkw, $P<0.001)$ showed a significant decrease compared to the control and sham groups ( $2.68 \pm 0.3$ and $2.16 \pm 0.2 \mu \mathrm{mol} / \mathrm{min}$ gkw, respectively), while the hydralazine group $(0.64 \pm 0.1 \mu \mathrm{mol} / \mathrm{min} \mathrm{gkw})$ did not show any significant difference with I-R group ( $\triangleright$ Table $\mathbf{1})$.

\section{Post-Treatment Effects of Hydralazine on Urinary Levels of Sodium ([Na] $\left.]_{4}\right)$, Potassium $\left([\mathrm{K}]_{u}\right)$, Creatinine $\left([\mathrm{Cr}]_{u}\right)$, and Osmolality (Osmol $\left.{ }_{u}\right)$}

The urine sodium concentration in the I-R group was significantly higher than the control group. $(28.72 \pm 8.4 \mu \mathrm{mol} / \mathrm{ml}$ vs. $65.73 \pm 6.9 \mu \mathrm{mol} / \mathrm{ml} ; P<0.001)$. The urine sodium concentration in the hydralazine group $(28.45 \pm 3.7 \mu \mathrm{mol} / \mathrm{ml})$ was not significantly different from sham $(32.33 \pm 3.9 \mu \mathrm{mol} / \mathrm{mL})$ and control groups. The urine sodium concentration decreased significantly in hydralazine group compared to the I-R group $(P<0.001)$.

The urine potassium concentration in the I-R group was significantly lower than the control group $(112.9 \pm 2.7 \mu \mathrm{mol} /$ $\mathrm{ml}$ vs. $133.63 \pm 13.6 \mu \mathrm{mol} / \mathrm{ml} ; P<0.01)$. The urine potassium concentration in the hydralazine group was significantly lower than the sham group $(45.03 \pm 6.3 \mu \mathrm{mol} / \mathrm{ml}$ vs. $120.28 \pm 9.13$ $\mu \mathrm{mol} / \mathrm{ml} ; P<0.001)$ and the I-R groups $(45.03 \pm 6.3 \mu \mathrm{mol} / \mathrm{ml}$ vs. $112.9 \pm 2.7 ; P<0.001)$. The urinary potassium concentration was not significantly different in the I-R group and sham group. The urinary creatinine concentration was not significantly different between the groups.

Urine osmolality in the I-R group was significantly lower than the control group. $\left(908.33 \pm 48.12 \mathrm{mOsm} / \mathrm{KgH}_{2} \mathrm{O}\right.$ vs. $\left.1515 \pm 70.5 \mathrm{mOsm} / \mathrm{KgH}_{2} \mathrm{O} ; P<0.001\right)$. Urine osmolality in the hydralazine group was significantly lower than the sham and control groups $\left(1285.33 \pm 162.08 \mathrm{mOsm} / \mathrm{KgH}_{2} \mathrm{O}\right.$ vs. $\left.1493.83 \pm 80.85 \mathrm{mOsm} / \mathrm{KgH}_{2} \mathrm{O} ; P<0.01\right)$, whereas significantly increased compared to the I-R group $(1285.33 \pm 162.08$ $\mathrm{mOsm} / \mathrm{KgH}_{2} \mathrm{O}$ vs. $\left.908.33 \pm 48.12 \mathrm{mOsm} / \mathrm{KgH}_{2} \mathrm{O} ; P<0.001\right)$ ( $\bullet$ Table 2).

\section{Post-Treatment Effects of Hydralazine on Plasma Concentrations of Sodium ([Na $\left.]_{p}\right)$, Potassium ( $\left.[\mathrm{K}]_{p}\right)$, Creatinine $\left([\mathrm{Cr}]_{p}\right)$, Urea ([BUN $\left.]_{p}\right)$, and Osmolality (Osmol $)$}

The results showed that plasma creatinine concentration significantly increased with I-R induction in comparison with control group $(1.24 \pm 0.35 \mathrm{mg} / \mathrm{dl}$ vs. $0.55 \pm 0.09 \mathrm{mg} / \mathrm{dl}$; $P<0.001)$ and sham group $(1.24 \pm 0.35 \mathrm{mg} / \mathrm{dl}$ vs. $0.64 \pm 0.08$ $\mathrm{mg} / \mathrm{dl} ; P<0.01)$. The plasma creatinine concentration in the hydralazine group exhibited significant reduction as compared to the I-R group $(0.71 \pm 0.1$ vs. $1.24 \pm 0.35 \mathrm{mg} / \mathrm{dl} ; P<0.001)$. There was no significant difference between the control and sham groups.

In I-R group, BUN was significantly higher than the control group $(47.81 \pm 5.9 \mathrm{mg} / \mathrm{dl}$ vs. $18.76 \pm 2.4 ; P<0.001)$ and the sham group $(47.81 \pm 5.9 \mathrm{mg} / \mathrm{dl}$ vs. $24.9 \pm 3.1 \mathrm{mg} / \mathrm{dl} ; P<0.01)$. There was no significant difference between the hydralazine group and the I-R group.

Plasma sodium concentration was not significantly different between I-R group and control group $(149.23 \pm 6.2 \mu \mathrm{mol} /$ $\mathrm{ml}$ vs. $152.1 \pm 6.1 \mu \mathrm{mol} / \mathrm{ml} ; P<0.01)$. In the hydralazine group, plasma sodium concentration significantly decreased compared to control group $(134.35 \pm 2.5 \mu \mathrm{mol} / \mathrm{ml}$ vs. $152.1 \pm 6.1$ $\mu \mathrm{mol} / \mathrm{ml} ; P<0.001)$, sham group $(134.35 \pm 2.5 \mu \mathrm{mol} / \mathrm{ml}$ vs. $144.45 \pm 6.7 \mu \mathrm{mol} / \mathrm{ml} ; P<0.05)$ and $\mathrm{I}-\mathrm{R}$ group $(134.35 \pm 2.5$ $\mu \mathrm{mol} / \mathrm{ml}$ vs. $149.23 \pm 6.2 \mu \mathrm{mol} / \mathrm{ml} ; P<0.001)$.

Plasma osmolality and potassium concentration were not significantly different among the four groups ( $\triangleright$ Table3). 


\begin{tabular}{|c|c|c|c|c|}
\hline Parameters groups & {$[\mathrm{Na}]_{u}(\mu \mathrm{mol} / \mathrm{ml})$} & {$[\mathrm{K}]_{\mathrm{u}}(\mu \mathrm{mol} / \mathrm{ml})$} & {$[\mathrm{Cr}]_{u}(\mathrm{mg} / \mathrm{dl})$} & $\mathrm{Osmol}_{\mathrm{u}}\left(\mathrm{mosm} / \mathrm{KgH}_{2} \mathrm{O}\right)$ \\
\hline Control & $28.72 \pm 8.4$ & $133.63 \pm 13.6$ & $1.38 \pm 0.2$ & $1515 \pm 70.5$ \\
\hline Sham & 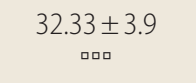 & $120.28 \pm 9.1$ & $1.33 \pm 0.3$ & $1493.83 \pm 80.8$ \\
\hline I-R & $\underset{* * *}{65.73 \pm 6.9}$ & $\underset{* *}{112.9 \pm 2.7}$ & $1.25 \pm 0.2$ & $\begin{array}{c}908.33 \pm 48.1 \\
* * * \\
+++\end{array}$ \\
\hline HYD + I-R & 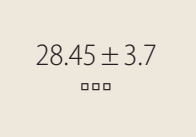 & $\begin{array}{c}45.03 \pm 6.3 \\
* * * \\
+++ \\
\text { 마 }\end{array}$ & $1.28 \pm 0.2$ & $\begin{array}{c}1258.33 \pm 162.08 \\
* * \\
++ \\
+\end{array}$ \\
\hline
\end{tabular}

$P<0.001^{* * *}, P<0.01^{* *}, P<0.05^{*}$ compared to the control group

$P<0.001+++, P<0.01++, P<0.05+$ compared to the sham group

$P<0.001$ 마 $P<0.01 \square, P<0.05 \square$ compared to the $I-R$ group

Results expressed in mean \pm standard deviation (SD) for 6 rats in each group

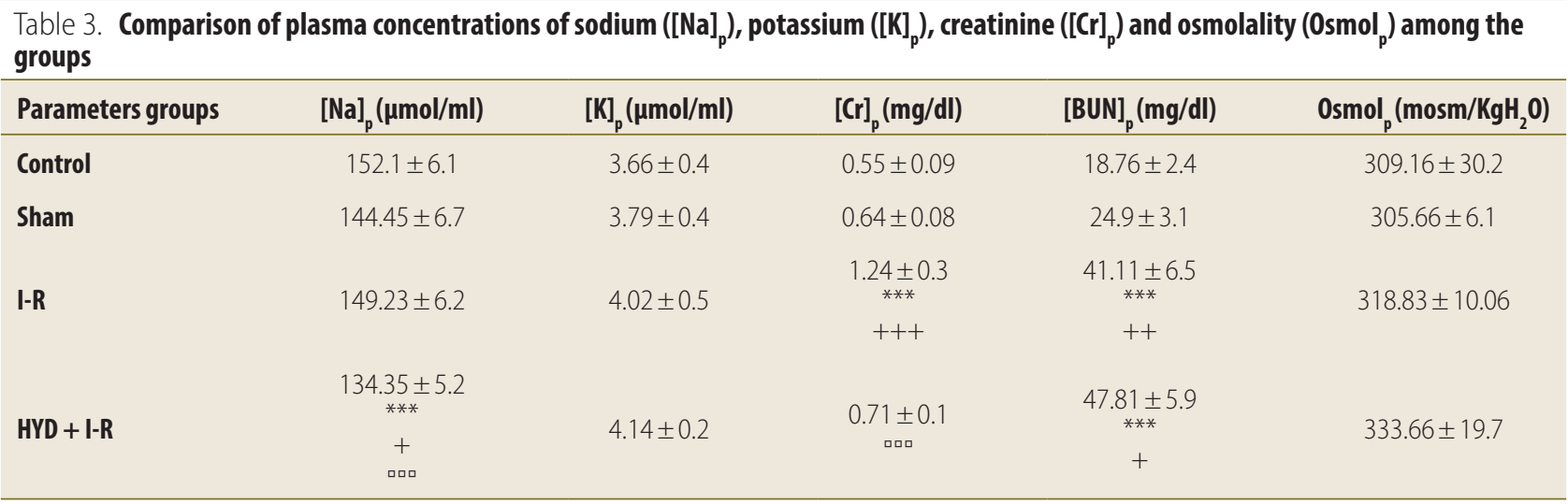

$P<0.001^{* * *}, P<0.01^{* *}, P<0.05^{*}$ compared to the control group

$P<0.001+++, P<0.01++, P<0.05+$ compared to the sham group

$P<0.001^{\square}, P<0.01^{\square}, P<0.05^{\square}$ compared to the I-R group

Results expressed in mean \pm standard deviation (SD) for 6 rats in each group

\section{Post-Treatment Effects of Hydralazine on MDA and FRAP Levels in Renal Tissue}

The results of this study indicated that MDA level per gram of kidney weight (gkw) significantly increased in I-R group $(35.68 \pm 6.4 \mu \mathrm{mol} / \mathrm{gkw} ; P<0.001)$ compared to control group $(15.33 \pm 4.21 \mu \mathrm{mol} / \mathrm{gkw})$ and sham group $(20.41 \pm 3.3 \mu \mathrm{mol} /$ gkw; $P<0.001)$. There was no significant difference in the MDA level in sham group compared to control group.

The MDA level in hydralazine-treated rats significantly reduce compared to the $\mathrm{I}-\mathrm{R}$ rats $(21.53 \pm 4.19 \mu \mathrm{mol} / \mathrm{gkw}$ vs. $35.68 \pm 6.4 \mu \mathrm{mol} / \mathrm{gkw} ; P<0.001$; $>$ Fig. 2a). There was no significant difference in the MDA levels of hydralazine group compared to the control and sham groups. FRAP level in the kidney tissue of I-R rats declined significantly compared to the control rats $(5.69 \pm 0.5 \mathrm{mmol} / \mathrm{gkw}$ vs. $8.61 \pm 1.06 \mathrm{mmol} / \mathrm{gkw}$; $P<0.001)$ and the sham group $(7.59 \pm 0.3 \mathrm{mmol} / \mathrm{gkw} ; P<0.001)$. FRAP levels of the control group was not significantly different from the sham group. FRAP level in the hydralazine-treated rats $(7.006 \pm 0.6 \mathrm{mmpl} / \mathrm{gkw})$ increased but was not significant compared to the I-R rats. FRAP level in the hydralazine group did not differ significantly from that of the control and sham groups ( $\triangleright$ Fig. 2 b) .

\section{Post-Treatment Effects of Hydralazine on Histopathological Changes (-Fig. 3)}

The results of this study showed extensive renal damage in the I-R rats that were significantly different compared to the control group (Grade 0), necrosis (Grade 3), and vacuolation (Grade 2) of tubular cells, increased of Bowman's space (Grade 1), presence of protein casts within the tubular lumen (Grade 2), scatter of cells into the lumen (Grade 3), reduce number of RBCs glomerular (Grade 1), and glomerular injury (Grade 2) were significantly different from the control group (Grade $0 ; P<0.05$ ).

In the hydralazine-treated rats, necrosis of the tubular cells (Grade 2) was significantly different in compared to the control and sham groups (Grade $0 ; P<0.05$ ) and significantly reduce in comparison with the I-R group (Grade 3; $P<0.05$ ) ( Fig. 3).

Hydralazine had no significant effects on increased Bowman's space (Grade 1), formation of protein casts (Grade 2), vacuolation (Grade 2), glomerular injury (Grade 2 ), cell scattering (Grade 2), and reduction in the number of glomerular RBCs (Grade 1) compared to the I-R group $(\triangleright$ Table 4). 

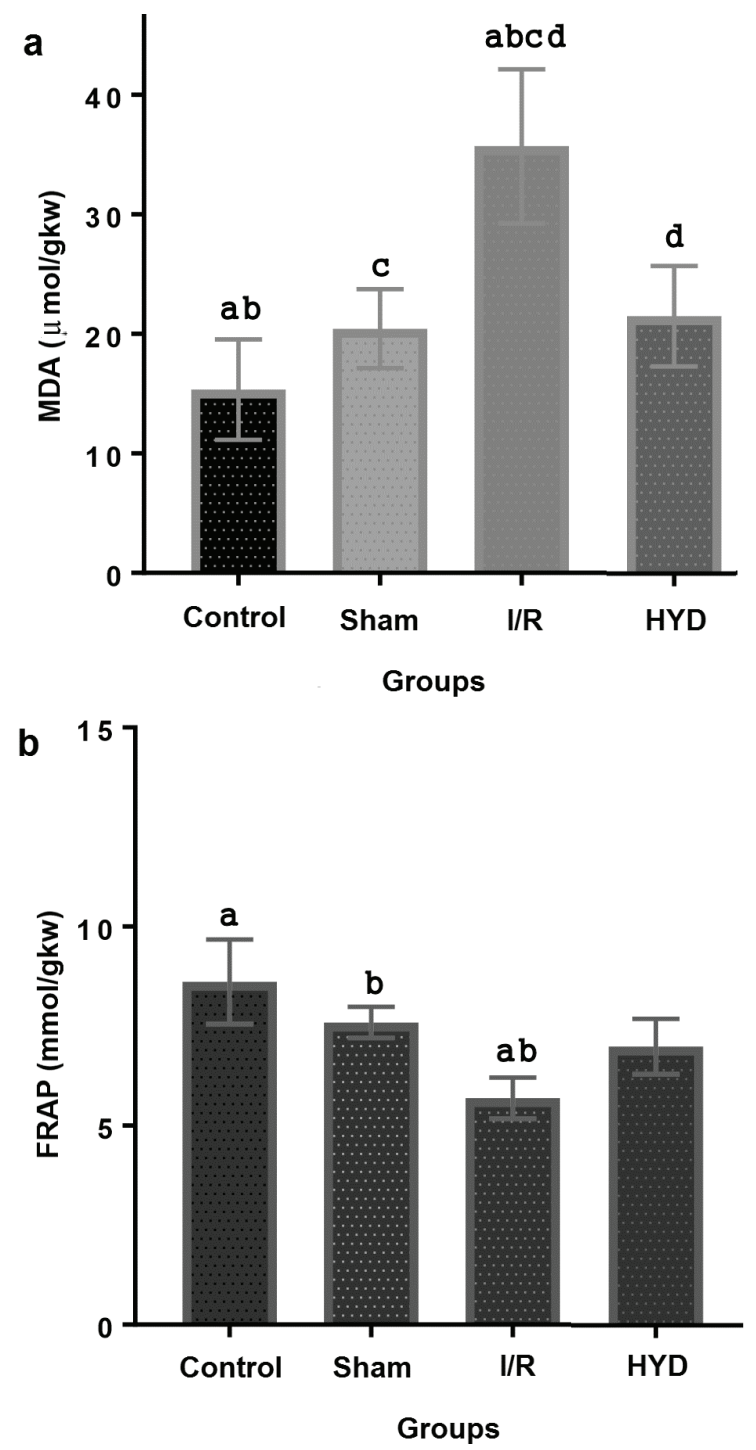

Fig. 2 Comparison of (a) MDA and (b) FRAP levels among the groups. Similar characters represent significant differences between the groups. Results are expressed as mean \pm the standard deviation (SD) for six rats in each group. Results are expressed on per gram kidney weight (gkw).

\section{Discussion}

The results of present study showed renal I-R caused AKI that is associated with increased plasma creatinine, BUN and decreased RBF and clearance of creatinine. ${ }^{24}$ Post-treatment with hydralazine significantly increased the renal clearance of creatinine and RBF and also improved sodium reabsorption and urine osmolality. Post-treatment with hydralazine had a nephroprotective effects on renal I-R. These results may be due to the fact that renal I-R injury leads to a lack of integrity and polarity of the epithelial cells with brush border destruction of the tubule. These changes promote the epithelial cellular downfall and the appearance of protein casts, lumen obstruction, and increased intratubular pressure. These factors caused a reduction in ion reabsorption, which during the reperfusion can lead to tubular obstruction and decreasing of GFR. Injured proximal tubules cannot reabsorbed sodium ions, which activates tubuloglomerular feedback. This feedback
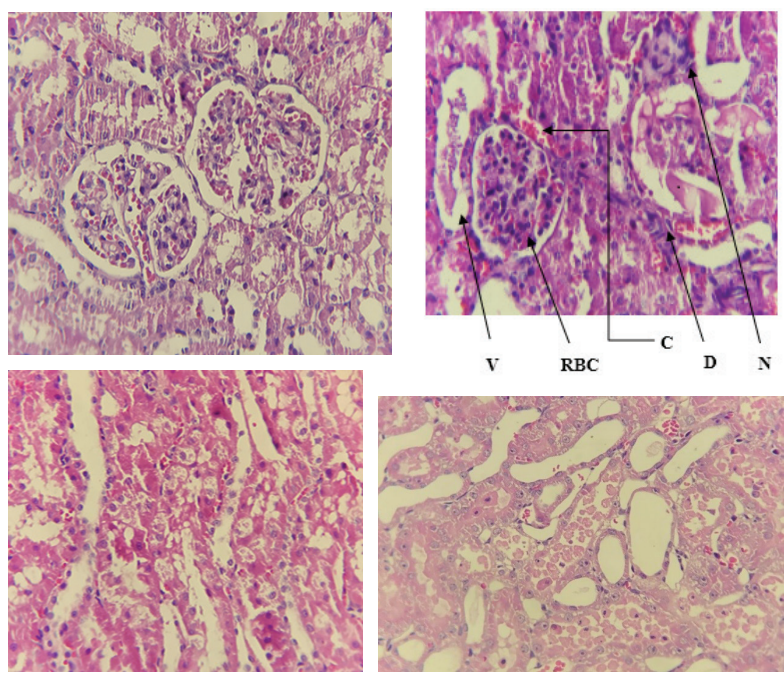

Fig. 3 Comparison of renal histological between different groups. (a) Control group with glomerular and normal tubular structure ( $\times 40)$; (b) I-R group with tubular cell necrosis, formation of protein casts inside the tubule lumen, cells scattering into the tubule lumen, vacuolation of tubular cells, increased Bowman's space and reduced number of red blood cells in glomerulus $(\times 40)$; (c) sham group with tubular cell necrosis $(\times 40)$; (d) Hydralazine group with increased Bowman's space, vacuolation of tubular cells and reduced tubular cell necrosis $(\times 40)$.

RBC: Red Blood Cell, N: Necrosis, C: Intratubular cast, D: Downfall, V: Vacuolization

significantly caused pre-glomerular arteriole constriction and reduce GFR. ${ }^{25}$

Hydralazine significantly increased the renal clearance of creatinine rate in the I-R rats. Previous studies indicated that hydralazine increased the formation of NO by the vascular endothelium and elevated intracellular cGMP levels. ${ }^{26,}$ ${ }^{27}$ Increased intracellular cGMP levels dilated afferent and efferent arterioles vasodilation leading to increase of GFR. In other study, Reetu R. Singh showed that NO increases GFR by increasing in the ultrafiltration coefficient; $\mathrm{NO}$ can also reduce TGF and cause constriction of pre-glomerular blood vessels. $^{28,29}$

Plasma electrolytes in the I-R rats were impaired in comparison with the control rats. $\mathrm{FE}_{\mathrm{Na}}$ increased in the I-R rats compared to the control rats but was not significant. $\mathrm{FE}_{\mathrm{K}}$ also increased in the I-R group. This increase indicates the injury to the tubular epithelial cells, especially the proximal tubule during I-R. ${ }^{25}$ Proximal tubules (PT, especially S3), thick ascending limb of Henle's loop (TAL) and external medulla are susceptible to I-R injury. ${ }^{30}$ In addition, I-R causes brush border destruction with reduced reabsorption of sodium by proximal tubules, impaired expression of tubular sodium transporters and unsuitable regulation of $\mathrm{Na}^{+} / \mathrm{K}^{+}$-ATPase expression in the basolateral membranes. ${ }^{19,30}$ In the I-R injury lead to direct injury of cells responsible for the secretion of potassium in the distal tubules and collecting ducts. ${ }^{31}$

Post-treatment of hydralazine in the I- $\mathrm{R}$ rats reduced urinary excretion of sodium compared to the I-R rats. Wu et al. showed the direct inhibitory effect of $\mathrm{NO}$ on renal $\mathrm{Na}^{+}$transport in proximal tubule and also the renal sympathetic nervous system that stimulated $\mathrm{Na}^{+}$transport in proximal tubule. Many studies showed the direct inhibitory effect of NO on $\mathrm{Na}+$ transport in the isolated tubule segments but not in the intact kidney. ${ }^{32}$ Hydralazine is not a first-line drug for treating 
Table 4. Comparison of necrosis level, protein casts, cell scattering, vacuolation, the reduced number of red blood cells, increased Bowman's capsular space, and glomerular injury

\begin{tabular}{|c|c|c|c|c|c|c|c|}
\hline $\begin{array}{l}\text { Parameters } \\
\text { groups }\end{array}$ & Cell necrosis & Vacuolation & $\begin{array}{l}\text { Increased Bowman's } \\
\text { capsular space }\end{array}$ & $\begin{array}{l}\text { Formation of } \\
\text { protein casts }\end{array}$ & Cell scattering & $\begin{array}{l}\text { Reduced number of } \\
\text { red blood cells }\end{array}$ & $\begin{array}{c}\text { Glomerular } \\
\text { injury }\end{array}$ \\
\hline Control & 0 & 0 & 0 & 0 & 0 & 0 & 0 \\
\hline \multirow{2}{*}{ Sham } & $\begin{array}{l}1 \\
*\end{array}$ & 0 & 1 & 0 & 0 & 0 & 0 \\
\hline & & 口 & $*$ & 口 & ㅁ & 口 & - \\
\hline \multirow{3}{*}{ I-R } & 3 & 2 & & 2 & 2 & 1 & 2 \\
\hline & * & * & $\begin{array}{l}1 \\
*\end{array}$ & * & * & * & * \\
\hline & + & + & & + & + & + & + \\
\hline \multirow{3}{*}{ HYD + I-R } & $\begin{array}{l}2 \\
*\end{array}$ & 2 & 1 & 2 & 2 & 1 & 2 \\
\hline & & * & * & * & * & * & $*$ \\
\hline & $\begin{array}{l}+ \\
\square\end{array}$ & + & & + & + & + & + \\
\hline
\end{tabular}

$P<0.05^{*}$ compared to the control group

$P<0.05+$ compared to the sham group

$P<0.05^{\square}$ compared to the $I-R$ group

Results expressed in mean \pm standard deviation (SD) for 6 rats in each group

hypertension due to increased activity of the sympathetic nervous system of the juxtamedullary cells, increased plasma renin activity and salt maintenance. ${ }^{33}$ Therefore, the activation of the renin-angiotensin system tends to neutralize the hydralazine vasodilator effect. ${ }^{34}$ In the cortical collecting duct, $\mathrm{NO}$ inhibits basolateral membrane potassium conductance. ${ }^{35}$

Urine osmolality was significantly decreased in the I-R rats compared to the control group because of impairment in the ability of the renal urine concentration. Inappropriate regulation of the AQPs and $\mathrm{Na}^{+}$transporter proteins in renal tubules and decreasing the expression of $\mathrm{Na}^{+} / \mathrm{K}^{+}$-ATPase in the thick descending limb of the external medulla that causing changes in sodium and water regulation under the influence of I-R injury. ${ }^{19}$ In the hydralazine-treated rats, urinary osmolality was significantly more than that of the I-R rats. Previous studies have shown that hydralazine reduces urinary volume due to water and sodium retention. ${ }^{36}$

In I-R rats, MDA levels significantly increased and FRAP levels significantly decreased in the kidney tissue. Previous studies have shown that I-R causes an imbalance between reactive oxygen species (ROS) sources and free radicals scavenger (reduced glutathione peroxidase, catalase, and superoxide dismutase). ${ }^{37}$ During the reperfusion phase, the oxygen free radicals caused lipid peroxidation which indicated AKI and necrosis. ${ }^{38}$ The MDA levels in the hydralazine-treated rats decreased compared to the I-R group and FRAP levels were increased compared to the I-R group. Previous studies have shown that treatment with hydralazine reduces the level of lipid peroxidation in myocardium in rats with spontaneous hypertension. ${ }^{39}$ The antioxidant effects of hydralazine are via the formation of ROS scavenger and inhibitor of $\mathrm{O} 2$-generation and peroxynitrite. ${ }^{40}$

In the present study, blood pressure was not significantly different among the groups. Regulation of blood pressure is via the short- and medium-term mechanisms, and the kidneys are long-term regulators of blood pressure that regulated blood volume via the renin-angiotensin system and function of aldosterone hormone.

In this study, in the I- R rats the RBF rates showed a significant decrease compared to the control and sham groups, which can be due to the fact that increased renal vascular resistance (RVR) can be a vascular response to ischemia. Increase of RVR may activate vasoactive factors, ROS and inflammatory pathways that can affect renal perfusion. Activation of the sympathetic nervous system, the renin-angiotensin system, prostaglandins, and endothelin A are main vasoconstrictor agents reducing RBF under I-R injury. ${ }^{41}$ In the sham group, the RBF was significantly lower than the control group, which could be due to the effects of anesthesia and surgical stress. Mercatello et al. has shown that anesthesia drugs influenced renal function not only directly, but also through changes in function of cardiovascular and endocrine system. Many barbiturates tend to reduce RBF. ${ }^{42}$ In the hydralazine-treated rats, the RBF was significantly increased in compare to the I- $\mathrm{R}$ rats. Previous studies indicated that hydralazine significantly reduces RVR and increased cardiac output which ultimately increases $\mathrm{RBF}^{43,44}$ The cellular mechanism of vasodilatory effect of hydralazine is not clearly determined, but it may be related to its calcium binding ability that is required for smooth muscle contraction of vessels, inhibiting IP3-induced calcium release from sarcoplasmic reticulum, and inhibiting myosin phosphorylation in arterial smooth muscle cells. ${ }^{27}$ Elkayam Uri et al. has shown that stimulating the production of endogenous NO in the kidney can consider as a therapeutic target for increasing RBF in patients with heart failure. ${ }^{45}$

In the present study, histopathological studies showed that compared to the control group, the I-R group induced vacuolation of tubular cells, degeneration of renal tubules, tubular cell necrosis, increased Bowman's space, formation of protein casts within the tubular lumen, cellular cell scattering into the tubular lumen, reduced number of RBCs in glomerula, and glomerular injury. In the hydralazine-treated rats, the improvement was not found in pathologic outcomes. The imbalance between expression and activity of eNOS and iNOS (decreased eNOS activity and increased iNOS expression) is responsible for the pathophysiology of I-R injury. ${ }^{46}$ Previous studies have not shown the improvement effects of hydralazine on the histological changes. ${ }^{47}$ Authors believe that the time of using hydralazine and also duration of treatment exert a very important role in pathological improvement. 


\section{Conclusion}

Regarding the results of the present study, post-treatment of hydralazine had therapeutic effects on AKI caused by I-R and improved ion reabsorption and excretion, hemodynamic parameters, antioxidant defense, and reduced MDA.

\section{IRB Ethical Approval Number}

The study Ethics Committee of Arak University of Medical Sciences approved this research under registration number IR.ARAKMU.REC. 1396.287.

\section{Informed Consent}

This research was not on humans. All ethical codes developed by the Monitoring Committee for Laboratory Animals at Arak University of Medical Sciences were complied with in the experiments conducted in the present study.

\section{Acknowledgement}

The financial support of this study was presented by the Research Deputy of Arak University of Medical Sciences.

\section{Support sources}

Deputy of Research and Education, Arak University of Medical Sciences

\section{References}

1. Makris K, Spanou L. Acute kidney injury: definition, pathophysiology and clinical phenotypes. Clin Biochem Rev. 2016;37(2):85.

2. Case J, Khan S, Khalid R, Khan A. Epidemiology of acute kidney injury in the intensive care unit. Critic Care Res Pract. 2013;2013.

3. Le Clef N, Verhulst A, D'Haese PC, Vervaet BA. Unilateral renal ischemiareperfusion as a robust model for acute to chronic kidney injury in mice. PLoS One. 2016;11(3):e0152153.

4. Padanilam BJ. Cell death induced by acute renal injury: a perspective on the contributions of apoptosis and necrosis. Am J Physiol-Renal Physiol. 2003;284(4):F608-F27.

5. Salvadori M, Rosso G, Bertoni E. Update on ischemia-reperfusion injury in kidney transplantation: Pathogenesis and treatment. World J Transpl. 2015;5(2):52.

6. Xu B, Bobek G, Makris A, Hennessy A. Antihypertensive methyldopa, labetalol, hydralazine, and clonidine reversed tumour necrosis factor-a inhibited endothelial nitric oxide synthase expression in endothelialtrophoblast cellular networks. Clin Exp Pharmacol Physiol. 2017;44(3): $421-7$.

7. Rocchiccioli JP. Hydralazine in Heart Failure: A Study of the Mechanism of Action in Human Blood Vessels: University of Glasgow; 2015.

8. Hendrickson MD, Poyton RO. Crosstalk between nitric oxide and hypoxiainducible factor signaling pathways: an update. Res Rep Biochem. 2015;5:147-61.

9. Packer M, Meller J, Medina N, Gorlin R, Herman MV. Dose requirements of hydralazine in patients with severe chronic congestive heart failure. Am J Cardiol. 1980;45(3):655-60.

10. Mikaelian I, Coluccio D, Hirkaler GM, Downing JC, Rasmussen E, Todd J, et al. Assessment of the toxicity of hydralazine in the rat using an ultrasensitive flow-based cardiac troponin I immunoassay. Toxicol Pathol. 2009;37(7): 878-81.

11. Hesketh EE, Czopek A, Clay M, Borthwick G, Ferenbach D, Kluth D, et al. Renal ischaemia reperfusion injury: A mouse model of injury and regeneration. Journal of visualized experiments: JoVE. 2014(88).

12. Suleyman Z, Sener E, Kurt N, Comez M, Yapanoglu T. The effect of nimesulide on oxidative damage inflicted by ischemia-reperfusion on the rat renal tissue. Renal Fail. 2015;37(2):323-31.
13. Zou L, Wang W, Liu S, Zhao X, Lyv Y, Du C, et al. Spontaneous hypertension occurs with adipose tissue dysfunction in perilipin-1 null mice. Biochim Biophys Acta (BBA)-Mol Basis Dis. 2016;1862(2):182-91.

14. Hajihashemi S, Hamidizad Z, Rahbari A, Ghanbari F, Motealeghi ZA. Effects of cobalamin (Vitamin B12) on gentamicin induced nephrotoxicity in rat. Drug Res. 2017;67(12):710-8.

15. Mukai K, Kuda Y, Shibamoto T, Tanida M, Kurata Y, Yokoyama H. Renal response to anaphylaxis in anesthetized rats and isolated perfused rat kidneys: Roles of nitric oxide. J Physiol Sci. 2018;68(5):689-97.

16. Hajihashemi S, Jafarian T, Ahmadi M, Rahbari A, Ghanbari F. Ameliorative effects of Zataria multiflora hydro-alcoholic extract on gentamicin induced nephrotoxicity in rats. Drug Res. 2018;68(07):387-94.

17. Cao Y, Gao X, Yang Y, Ye Z, Wang E, Dong Z. Changing expression profiles of long non-coding RNAs, mRNAs and circular RNAs in ethylene glycolinduced kidney calculi rats. BMC Genom. 2018;19(1):660.

18. Antony AS, Gomathy S, Rajmohan T, Anoop P, Issaic C. Pharmacological evaluation of curcumin for its nephroprotective activity in 5/6 nephrectomized rat model. Drug Invent Today. 2018;10(1).

19. Kristensen MLV, Kierulf-Lassen C, Nielsen PM, Krag S, Birn H, Nejsum $L N$, et al. Remote ischemic perconditioning attenuates ischemia/ reperfusion-induced downregulation of AQP2 in rat kidney. Physiol Rep. 2016;4(13):e12865.

20. Chole RH, Patil RN, Basak A, Palandurkar K, Bhowate R. Estimation of serum malondialdehyde in oral cancer and precancer and its association with healthy individuals, gender, alcohol, and tobacco abuse. J Cancer Res Therap. 2010;6(4):487.

21. Ustundag Y, Huysal K, Kahvecioglu S, Demirci H, Yavuz S, Sambel M, et al. Establishing reference values and evaluation of an in-house ferric reducing antioxidant power (FRAP) colorimetric assay in microplates. Eur Res J. 2016;2(2):126.

22. Ahmadi M, Hajihashemi S, Rahbari A, Ghanbari F. The effects of diclofenac on renal toxicity disorders induced by gentamicin in rats. J Babol Univ Med Sci. 2018;20(2):33-41.

23. Yu C, Qi D, Sun J-F, Li P, Fan H-Y. Rhein prevents endotoxin-induced acute kidney injury by inhibiting NF-kB activities. Scient Rep. 2015;5:11822.

24. Basile DP, Anderson MD, Sutton TA. Pathophysiology of acute kidney injury. Comprehen Physiol. 2011;2(2):1303-53.

25. Chatauret N, Badet L, Barrou B, Hauet T. Ischemia-reperfusion: From cell biology to acute kidney injury. Prog urol. 2014;24:S4-S12.

26. Miller WL, Cavero PG, Aarhus LL, Heublein DM, Burnett Jr JC. Endothelinmediated cardiorenal hemodynamic and neuroendocrine effects are attenuated by nitroglycerin in vivo. Am J Hypertens. 1993;6(2):156-63.

27. McComb MN, Chao JY, Ng TM. Direct vasodilators and sympatholytic agents. J Cardiovasc Pharmacol Therap. 2016;21(1):3-19.

28. Krishnan S, Kraehling J, Eitner F, Bénardeau A, Sandner P. The impact of the nitric oxide (NO)/soluble guanylyl cyclase (SGC) signaling cascade on kidney health and disease: a preclinical perspective. Int J Mol Sci. 2018;19(6):1712.

29. Singh RR, Easton LK, Booth LC, Schlaich MP, Head GA, Moritz KM, et al. Renal nitric oxide deficiency and chronic kidney disease in young sheep born with a solitary functioning kidney. Scient Rep. 2016;6:26777.

30. Vallon V. Tubular transport in acute kidney injury: relevance for diagnosis, prognosis and intervention. Nephron. 2016;134(3):160-6.

31. Palmer BF. Potassium homeostasis in chronic kidney disease. Nephrol News Issues. 2016;30(4):suppl 8-10, 2-3.

32. Mount $P$, Power DA. Nitric oxide in the kidney: functions and regulation of synthesis. Acta Physiol. 2006;187(4):433-46.

33. Li C, Salisbury R, Ely D. Hydralazine reverses stress-induced elevations in blood pressure, angiotensin II, testosterone, and coronary pathology in a social colony model. ISRN Pathol. 2011;2011.

34. Haynes W, Hand M, Dockrell M, Eadington D, Lee M, Hussein Z, et al. Physiological role of nitric oxide in regulation of renal function in humans. Am J Physiol-Renal Physiol. 1997;272(3):F364-F71.

35. Sharma S. Nitric oxide and the kidney. Ind J Nephrol. 2004;14(3):77-84.

36. Grover A, Daniels E. Calcium and Contractility: Smooth Muscle: Springer Science \& Business Media; 2012.

37. Sabbahy ME, Vaidya VS. Ischemic kidney injury and mechanisms of tissue repair. Wiley Interdisc Rev Syst Biol Med. 2011;3(5):606-18.

38. Hutchens MP, Dunlap J, Hurn PD, Jarnberg PO. Renal ischemia: does sex matter? Anesth Analg. 2008;107(1):239-49.

39. Cabell KS, Ma L, Johnson P. Effects of antihypertensive drugs on rat tissue antioxidant enzyme activities and lipid peroxidation levels. Biochem Pharmacol. 1997:54(1):133-41.

40. Cheng YW, Chiou GC. Antioxidant effect of hydralazine on retinal pigment epithelial cells and its potential use in the therapy of age-related macular degeneration. Int J Ophthalmol. 2008;8(6):1059-64. 
41. P Basile D, C Yoder M. Renal endothelial dysfunction in acute kidney ischemia reperfusion injury. Cardiovasc Haematol Disord-Drug Targets (Formerly Curr Drug Targets-Cardiovasc Hematol Disord.). 2014;14(1):3-14

42. Mercatello A, editor Changes in renal function induced by anesthesia. Ann franc anesth reanim.; 1990.

43. Elkayam U, Weber L, Campese VM, Massry SG, Rahimtoola SH. Renal hemodynamic effects of vasodilation with nifedipine and hydralazine in patients with heart failure. J Am Coll Cardiol. 1984:4(6):1261-7.

44. Zeisberg E, Zeisberg M. A rationale for epigenetic repurposing of hydralazine in chronic heart and kidney failure. J Clin Epigenet. 2016;2(1).
45. Elkayam U, Cohen G, Gogia H, Mehra A, Johnson JV, Chandraratna PAN. Renal vasodilatory effect of endothelial stimulation in patients with chronic congestive heart failure. J Am Coll Cardiol. 1996;28(1):176-82.

46. Badavi M, Naseri MKG, Pirmoradi L, Hosseini F. Beta carotene modulates nitric oxide production in the renal ischemia/reperfusion injury in rat. Zahedan J Res Med Sci. 2017;19(3).

47. Zuckerman R, Patel M, Costanzo EJ, Dounis H, Haj RA, Seyedali S, et al. Hydralazine-associated adverse events: A report of two cases of hydralazine-induced ANCA vasculitis. Braz J Nephrol. 2018(AHEAD)324

This work is licensed under a Creative Commons Attribution-NonCommercial 3.0 Unported License which allows users to read, copy, distribute and make derivative works for non-commercial purposes from the material, as long as the author of the original work is cited properly. 